\title{
Mapping, expression and regulation of the TR $\alpha$ gene in porcine adipose tissue
}

\author{
Z.-W. Cai, Y.-F. Sheng, L.-F. Zhang, Y. Wang, X.-L. Jiang, \\ Z.-Z. Lv and N.-Y. Xu
}

College of Animal Science, Zhejiang University, Hang Zhou, P.R. China

Corresponding author: N.-Y. Xu

E-mail: nyxu@zju.edu.cn

Genet. Mol. Res. 10 (3): 1320-1330 (2011)

Received October 17, 2010

Accepted December 14,2010

Published July 5, 2011

DOI 10.4238/vol10-3gmr1113

\begin{abstract}
Thyroid hormone receptors (TR) are members of the nuclear receptor superfamily. There are at least two TR isoforms, $\operatorname{TR} \alpha$ and $\operatorname{TR} \beta$. The TR $\alpha$ isoform plays a critical role in mediating the action of thyroid hormone in adipose tissue. We mapped the porcine TR $\alpha$ gene to chromosome 12 p11-p13, by using the ImpRH panel. We examined tissue-localization of TR $\alpha$ and determined expression patterns of TR $\alpha$ in porcine adipose tissue with quantitative real-time PCR. TR $\alpha$ was expressed in all tissues, including heart, liver, spleen, stomach, pancreas, brain, small intestine, skeletal muscle, and subcutaneous adipose tissue. In the adipose tissue, the expression of $\mathrm{TR} \alpha$ decreased postnatally. Compared to Yorkshire pigs, Jinhua pigs had significantly lower expression levels of TR $\alpha$ gene in the subcutaneous fat tissue. The expression levels of $\beta 2-A R$, HSL and ATGL were also significantly lower in Jinhua pigs than in Yorkshire pigs. However, no significant differences in PPAR $\gamma$ and SREBP-1C expression levels were found between Jinhua and Yorkshire pigs. Incubation of porcine adipose tissue explants with high doses of isoproterenol (100 and $1000 \mathrm{nM}$ ) significantly increased
\end{abstract}


the expression levels of TR $\alpha$. We conclude that there is considerable evidence that TR $\alpha$ plays an important role in fat deposition in porcine adipose tissue.

Key words: Thyroid hormone; TR $\alpha$; Adipose tissue; Fat deposition

\section{INTRODUCTION}

Thyroid hormone plays a central role in normal growth, development, differentiation, and energy metabolism in all vertebrates (Yen, 2001). Recently, some insights into the thyroidal regulation of fat tissue have been obtained from animal studies. Thyroid hormone modulates the development and metabolism of adipose tissue under both normal physiological and pathological conditions. The numbers of adipocytes increase and decrease in hyper- and hypothyroid animals, respectively (Picon and Levacher, 1979). It has been reported that thyroid hormone is an adipogenic factor in 3T3-L1 adipocytes (Jiang et al., 2004). However, thyroid hormone has also been found to increase basal oxygen consumption and lipolysis (Oppenheimer et al., 1991; Viguerie et al., 2002). The contradictory findings may be due to distinct experimental conditions, because of the intricacy of the effects of thyroid hormone on adipose tissue. The mechanism by which thyroid hormone influences adipose tissue metabolism currently is well defined, but likely involves transcription regulation of important target genes by its receptors (TRs). Mammals have two principal TR isoforms (TR $\alpha$ and TR $\beta$ ); each of them gives rise to multiple isoforms via alternate splicing or alternate start codon usage (Munoz and Bernal, 1997). Recently studies have shown that TR $\alpha$ isoform is predominantly expressed in adipocytes and plays a pivotal role in mediating the action of thyroid hormone in adipocytes (Ying et al., 2007; Pelletier et al., 2008; Ortega et al., 2009). Although TR $\alpha$ has been implicated as a major factor in the regulation of fat deposition, little is known about the age-related changes of TR $\alpha$ gene expression in porcine adipose tissue; there is also a lack of information on breed differences. The Jinhua pig is one of the most important local Chinese breeds; it is characterized by high reproductive performance, but has a low growth rate and accentuated fat deposition (Miao et al., 2009). Yorkshire pigs are well known for their high growth rate, but have a low degree of fat deposition and a poor reproductive performance. We decided to compare the expression of the TR $\alpha$ gene in adipose tissue from these two porcine genotypes to help extend our understanding of the role of TR $\alpha$ in regulating fat metabolism.

\section{MATERIAL AND METHODS}

\section{Animals}

The experimental procedures used in this study were approved by the Institutional Animal Care and Use Committee of Zhejiang University. The tissue distribution and ontogeny studies were performed on male Yorkshire pigs. Tissue distribution was studied at 150 days. Ontogeny of expression levels was examined at 1, 45, 60, 90, and 120 days, with six pigs per group. Jinhua and Yorkshire male pigs (150 days, six pigs of each breed) were used for the breed difference study. All pigs had ad libitum access to an experimental diet and water. 
Before slaughter, the pigs were weighed. After slaughter, back fat thickness was measured using a ruler on the left side of each carcass at five locations (shoulder, thorax-waist, buttock, between the 13th and 14th rib, and between the 6th and 7th rib). Nine tissues including heart, liver, spleen, stomach, pancreas, brain, small intestine, skeletal muscle, and subcutaneous adipose tissue were freshly collected and immediately frozen in liquid nitrogen for the tissue distribution study. The samples were collected and rapidly frozen in liquid nitrogen, then stored at $-70^{\circ} \mathrm{C}$ for isolation of total RNA and analysis of gene expression.

\section{Total RNA isolation and cDNA synthesis}

Total RNA from adipose tissue was isolated using Trizol reagent (Invitrogen) and chloroform, according to manufacturer instructions. The RNA was run through a purification process, using an RNeasy Mini Kit (Qiagen). The quality and concentration of the RNA were determined by measuring absorbance at 260 and $280 \mathrm{~nm}$, and RNA integrity was confirmed by agarose gel electrophoresis. Approximately $1 \mu \mathrm{g}$ total RNA was used to synthesize the first cDNA, using an MMLV-RT kit (Promega), according to the manufacturer protocol.

\section{Quantitative real-time polymerase chain reaction (PCR)}

Quantitative real-time PCR was performed using the ABI StepOne Plus Real-Time PCR Detection System (Applied Biosystems). Primers were designed to be of an appropriate length and had an optimal annealing temperature of $60^{\circ} \mathrm{C}$ (Table 1). Melt curve analysis was performed on all real-time PCRs to confirm specificity and identity of the real-time PCR products. A nontemplate control was run for every assay. A constant amount of cDNA $(1 \mu \mathrm{L})$ was used for each real-time RT-PCR measurement and three technical replicates were performed in duplicate for

\begin{tabular}{|c|c|c|c|c|}
\hline Target & Primer sequence $\left(5^{\prime} \rightarrow 3^{\prime}\right)$ & GeneBank number & Product length (bp) & Temperature $\left({ }^{\circ} \mathrm{C}\right)$ \\
\hline $\begin{array}{l}\text { RH mapping } \\
\text { sense } \\
\text { antisense }\end{array}$ & $\begin{array}{l}\text { 5'-TTGACAAGATCACCCGCAATC-3' } \\
\text { 5'-CAGCAGTGGGCTCTGGTCG-3' }\end{array}$ & AJ005797 & 193 & 58 \\
\hline $\begin{array}{l}\operatorname{TR} \alpha \\
\text { sense } \\
\text { antisense }\end{array}$ & $\begin{array}{l}\text { 5'-GGCTGTGCTGCTAATGTCAA-3' } \\
\text { 5'-TCGACTTTCATGTGGAGGAA-3' }\end{array}$ & AJ005797 & 213 & 60 \\
\hline $\begin{array}{l}\text { PPAR } \gamma \\
\text { sense } \\
\text { antisense }\end{array}$ & $\begin{array}{l}\text { 5'-GCCCTTCACCACTGTTGATT-3' } \\
\text { 5'-GAGTTGGAAGGCTCTTCGTG-3' }\end{array}$ & NM_214397 & 201 & 60 \\
\hline $\begin{array}{l}\text { SREBP-1C } \\
\text { sense } \\
\text { antisense }\end{array}$ & $\begin{array}{l}\text { 5'-GCG ACG GTG CCT CTG GTA GT-3' } \\
\text { 5'-CGC AAG ACG GCG GAT TTA-3' }\end{array}$ & AF0924229 & 218 & 60 \\
\hline $\begin{array}{l}\text { HSL } \\
\text { sense } \\
\text { antisense }\end{array}$ & $\begin{array}{l}\text { 5'-GCTCCCATCGTCAAGAATC-3' } \\
\text { 5'-TAAAGCGAATGCGGTCC-3' }\end{array}$ & AJ000482 & 262 & 60 \\
\hline $\begin{array}{l}\text { ATGL } \\
\text { sense } \\
\text { antisense }\end{array}$ & $\begin{array}{l}\text { 5'-AGT TCA GCC TGC GCA ACC TC-3' } \\
\text { 5'-AGG GCA CCA TCA TGG CTG-3' }\end{array}$ & EF583921 & 220 & 60 \\
\hline $\begin{array}{l}\beta 2 \text {-AR } \\
\text { sense } \\
\text { antisense }\end{array}$ & $\begin{array}{l}\text { 5'-GGC TGC CCT TCT TCA TCG TCA AC-3' } \\
\text { 5'-AGC CCA CCC AGT TTA GCA GGA TGT-3' }\end{array}$ & NM_001128436 & 90 & 60 \\
\hline $\begin{array}{l}\beta \text {-actin } \\
\text { sense } \\
\text { antisense }\end{array}$ & $\begin{array}{l}\text { 5'-ACT GGG ACG ACA TGG AGA AGA-3' } \\
\text { 5'-TTG GCT TTG GGG TTC AGG-3' }\end{array}$ & AY550069 & 114 & 60 \\
\hline
\end{tabular}


each gene. The amplifications were performed in $20-\mu \mathrm{L}$ reaction mixtures containing $10.4 \mu \mathrm{L}$ SYBR Premix Ex Taq (2X) (Takara), $0.4 \mu \mathrm{L}$ of each primer $(10 \mu \mathrm{M}), 7.8 \mu \mathrm{L}$ distilled water and $1.0 \mu \mathrm{L} \mathrm{cDNA}$. The cycling conditions consisted of 40 cycles of $95^{\circ} \mathrm{C}$ for $5 \mathrm{~min}, 60^{\circ} \mathrm{C}$ for $30 \mathrm{~s}$ and $72^{\circ} \mathrm{C}$ for $20 \mathrm{~s}$. The PCR efficiencies for selected genes and $\beta$-actin were close to 1 . The method of $2^{-\Delta \Delta C \mathrm{t}}$ was used to analyze the real-time PCR data (Livak and Schmittgen, 2001).

\section{Primary adipose tissue culture}

For in vitro experiments, subcutaneous adipose tissue was collected from four crossbred barrows (Landrace x Yorkshire) at 210 days of age. Subcutaneous adipose tissue samples were collected between the 2 nd and 4 th thoracic vertebrae and prepared according to previously described methods (Ramsay and Richards, 2007). Briefly, dissected subcutaneous adipose tissue was diced and placed in Hanks buffer $\left(37^{\circ} \mathrm{C}, \mathrm{pH} 7.4\right)$. Adipose tissue was sliced using a microtome (Faulhaber et al., 1972). The slices were then cut into explants. Adipose tissue explants were then transferred to 12-well tissue culture plates containing $1 \mathrm{~mL}$ DMEM/F12 with $25 \mathrm{mM}$ HEPES, 0.5\% BSA, $\mathrm{pH} 7.4$, and the various hormone supplements of interest. Triplicate tissue slices for each pig were incubated with each medium (basal medium, isoproterenol supplemented medium) in $5 \% \mathrm{CO}_{2}$ at $37^{\circ} \mathrm{C}$ for $24 \mathrm{~h}$. At the end of the incubation period, tissue samples from these incubations were blotted dry and frozen in liquid nitrogen for later analysis of gene expression by real-time PCR analysis. Isoproterenol was used for in vitro experiments, as it is a universal $\beta$-receptor agonist in swine (Mersmann, 1998). Isoproterenol was solubilized in distilled water and filtered. Isoproterenol $(10,100$ and $1000 \mathrm{nM}$ ) was added as a supplement to medium for 24-h incubations and compared to a basal medium (control).

\section{Radiation hybrid mapping}

Radiation hybrid (RH) mapping was performed using the INRA-University of Minnesota porcine radiation hybrid (IMpRH) panel (Yerle et al., 1998). Pig-specific primers were designed to amplify porcine genomic DNA within the porcine IMpRH panel (Table 1). PCR was performed in a volume of $25 \mu \mathrm{L}$, consisting of $50 \mathrm{ng}$ genomic DNA, $0.4 \mu \mathrm{M}$ of each primer, 1.5 $\mathrm{mM} \mathrm{MgCl}, 200 \mu \mathrm{M}$ dNTPs, $2.5 \mu \mathrm{L} 10 \mathrm{X}$ buffer and $0.5 \mathrm{U}$ DNA polymerase (Takara, Dalian, China). The PCR conditions were $94^{\circ} \mathrm{C}$ for 3 min, followed by 30 cycles of $94^{\circ} \mathrm{C}$ for $50 \mathrm{~s}, 58^{\circ} \mathrm{C}$ for $45 \mathrm{~s}$, and $72^{\circ} \mathrm{C}$ for $40 \mathrm{~s}$, and a final extension step at $72^{\circ} \mathrm{C}$ for $7 \mathrm{~min}$. PCRs with porcine genomic DNA and hamster genomic DNA were performed as positive and negative controls, respectively. The amplification products were separated on a $2 \%$ agarose gel. The PCR results were recorded and analyzed on (http://imprh.toulouse.inra.fr/) for RH mapping (Milan et al., 2000).

\section{Data analysis}

All experimental data are reported as means \pm SEM. One-way analysis of variance (ANOVA) and two-tailed Student $t$-tests were performed to analyze the growth performance and gene expression data. Effects were considered to be significant at $\mathrm{P}<0.05$. All statistical analysis was performed using SPSS 13.0 for windows (SPSS Inc., Chicago, IL, USA). 


\section{RESULTS}

\section{Chromosome mapping}

We localized the porcine TR $\alpha$ gene to SSC $12 \mathrm{P}^{11-13}$ by using the IMpRH. The two-point analysis from IMpRH mapping indicated that this gene is closely linked to SW943 (LOD = 5.71; Figure 1). Previously, the homologous human gene was mapped to HSA17 $\mathrm{q}^{11}$. These results were as expected based on the established conservation of synteny between human-pig maps.

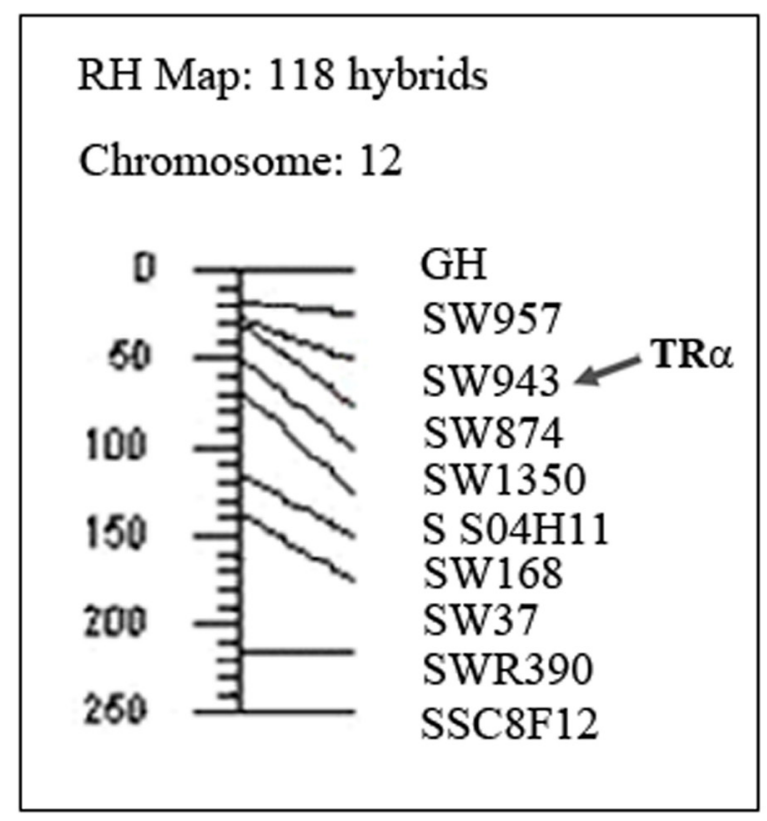

Figure 1. Radiation hybrid (RH) mapping of the porcine TR $\alpha$ gene onto porcine chromosome 12.

\section{Tissue distribution of the porcine $\mathrm{TR} \alpha$ gene}

The quantitative real-time PCR method was used to determine the tissue distribution of expression of the porcine TR $\alpha$ gene. The mRNA of TR $\alpha$ was expressed in all the tissues (Figure 2). Among the tissues analyzed, the expression of the TR $\alpha$ gene was highest in brain and white adipose tissues. The considerable expression of TR $\alpha$ mRNA found in fat tissue suggests that part of the effects of TR $\alpha$ on fat metabolism is mediated directly on adipose, besides the classic hormone cascade of the HPT axis.

\section{Postnatal change of the expression of $\mathrm{TR} \alpha$ gene in porcine adipose tissue}

In order to have a detailed assessment of the postnatal development changes in TR $\alpha$ gene expression in porcine adipose tissue, we collected subcutaneous fat tissue from 1-, 45-, 60-, 90-, 120-, and 150-day-old pigs ( $\mathrm{N}=6$ for each time) and expression of TR $\alpha$ at mRNA 


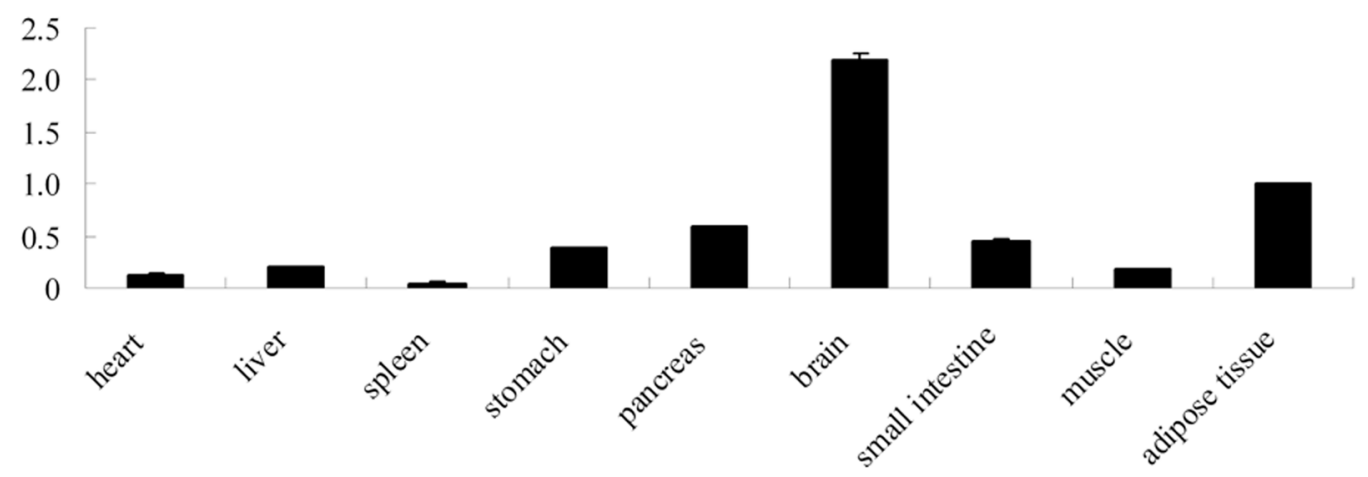

Figure 2. Expression analysis of TR $\alpha$ gene in various porcine tissues. Mean mRNA levels in nine tissues were analyzed by quantitative real-time RT-PCR. Data are $2^{-\Delta \Delta C t}$ levels calculated relative to the white adipose tissue. All values are reported as means $\pm \mathrm{SEM}$.

levels was quantified by real-time PCR analyses. Real time TR-PCR data showed that porcine subcutaneous adipose tissue expresses high levels of TR $\alpha$ at birth, and that it decreases postnatally (Figure 3).

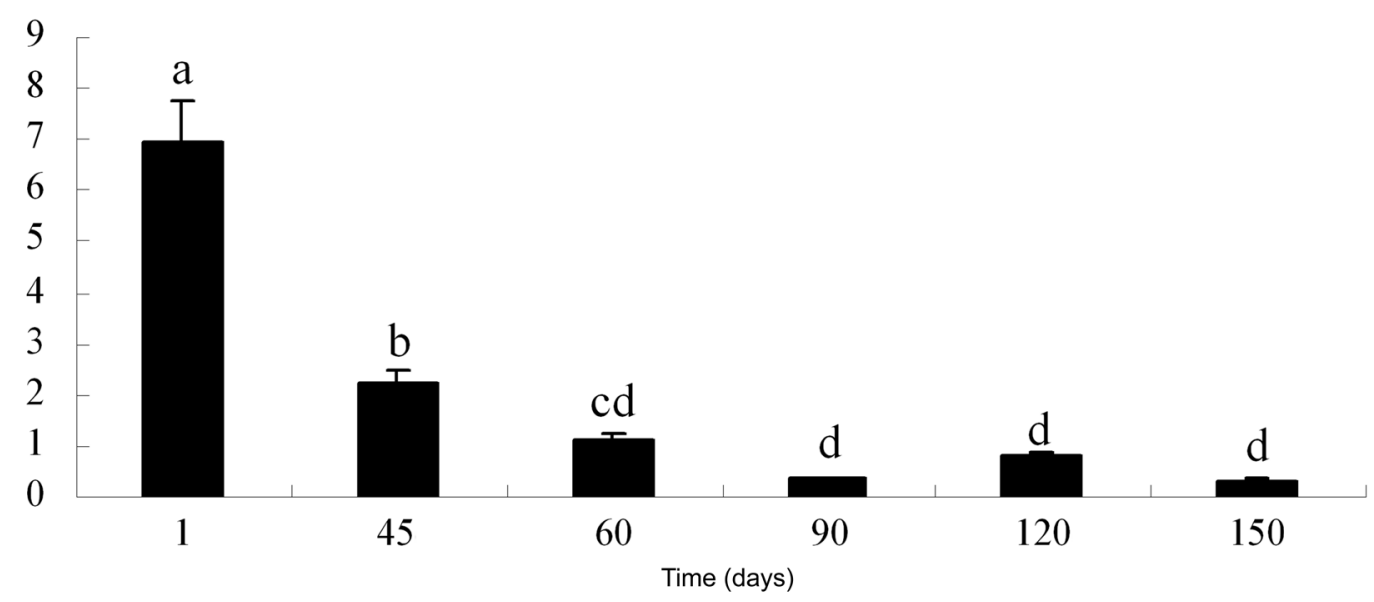

Figure 3. Postnatal expression of $\mathrm{TR} \alpha$ gene in porcine subcutaneous adipose tissue. All values are reported as means \pm SEM for $\mathrm{N}=6$ per group. Means not sharing a common letter differ significantly $(\mathrm{P}<0.01)$.

\section{Body weight, back fat thickness and $\mathrm{TR} \alpha \mathrm{mRNA}$ levels in Jinhua and Yorshire pigs}

Jinhua pigs grow more slowly than Yorkshire pigs. At 150 days, the body weight of Jinhua pigs was lower than that of Yorkshire pigs $(\mathrm{P}<0.01$; Figure $4 \mathrm{~A})$, but average back fat thickness was higher in Jinhua compared with Yorkshire pigs $(\mathrm{P}<0.01$; Figure 4B). In subcutaneous adipose tissue, the expression of TR $\alpha$ (Figure 4C), $\beta 2$-AR (Figure 4E), HSL (Figure $4 \mathrm{G}$ ), and ATGL (Figure 2H) mRNA in Jinhua pigs were all lower than in Yorkshire pigs $(\mathrm{P}<$ 0.05). However, the expression of PPAR $\gamma$ (Figure 4D) and SREBP-1C (Figure 4F) mRNA in Jinhua pigs were only slightly higher than in Yorkshire pigs $(\mathrm{P}=0.719$ and $\mathrm{P}=0.484)$. 
A

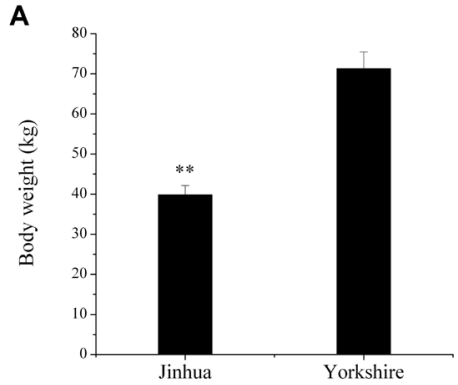

C

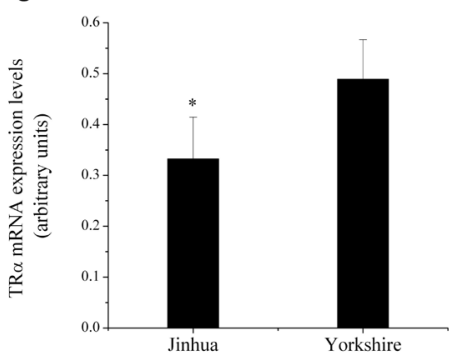

E

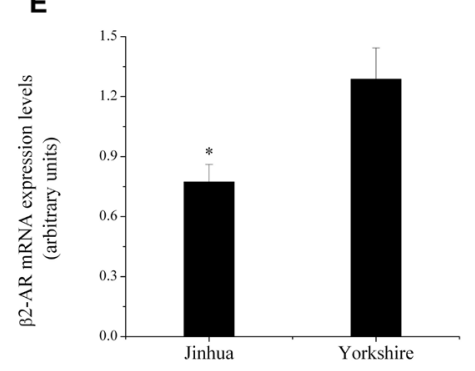

G

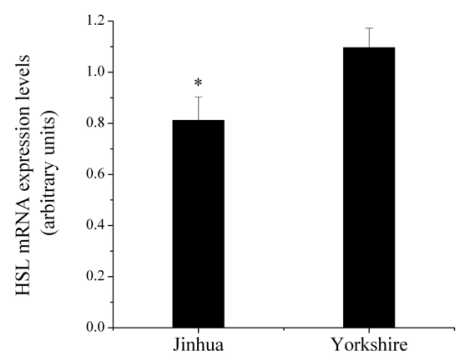

B

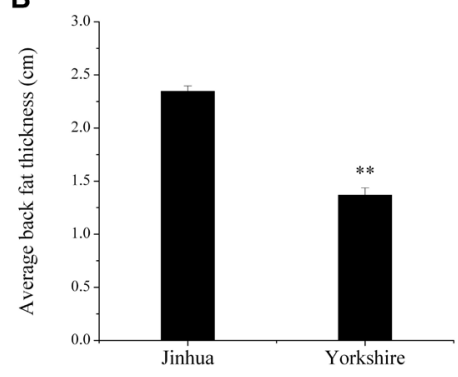

D

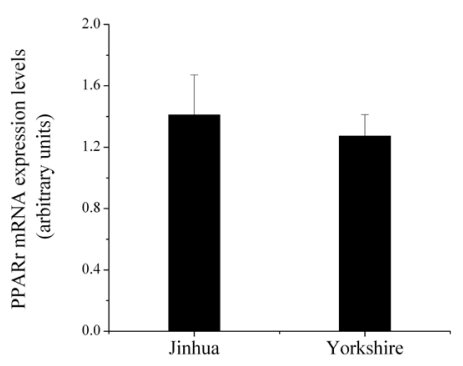

$\mathbf{F}$

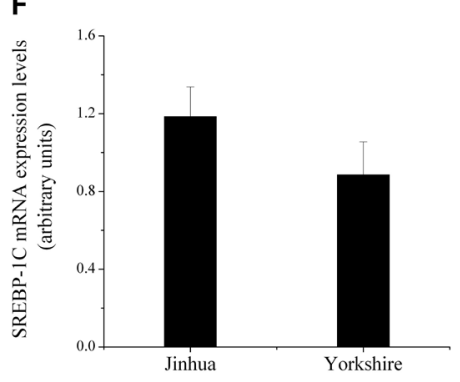

H

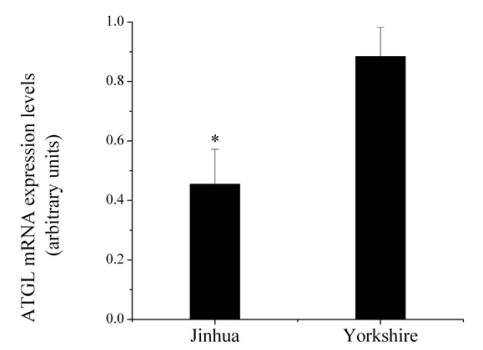

Figure 4. Body weight (A), back fat thickness (B) and mRNA levels of TR $\alpha$ (C), PPAR $\gamma(\mathrm{D}), \beta 2-\mathrm{AR}$ (E), SREBP$1 \mathrm{C}(\mathrm{F})$, HSL $(\mathrm{G})$, and ATGL $(\mathrm{H})$ in Jinhua and Yorshire pigs. All values are reported as means $\pm \mathrm{SEM}$ for $\mathrm{N}=6$ per group $(* \mathrm{P}<0.05)$. 


\section{Regulation of $\mathrm{TR} \alpha$ gene expression by isoproterenol in vitro}

Isoproterenol treatment significantly increased gene expression of TR $\alpha$ in porcine adipose tissue explants. Compared with the control $(0 \mathrm{nM})$, treatment with high doses of isoproterenol (100 and $1000 \mathrm{nM}$ ) significantly increased the mRNA levels of TR $\alpha$ in porcine adipose tissue explants $(\mathrm{P}<0.05$; Figure 5). However, $10 \mathrm{nM}$ isoproterenol treatment did not significantly change the mRNA levels of TR $\alpha$ in the adipose tissue explants compared with the control $(\mathrm{P}=0.304)$.
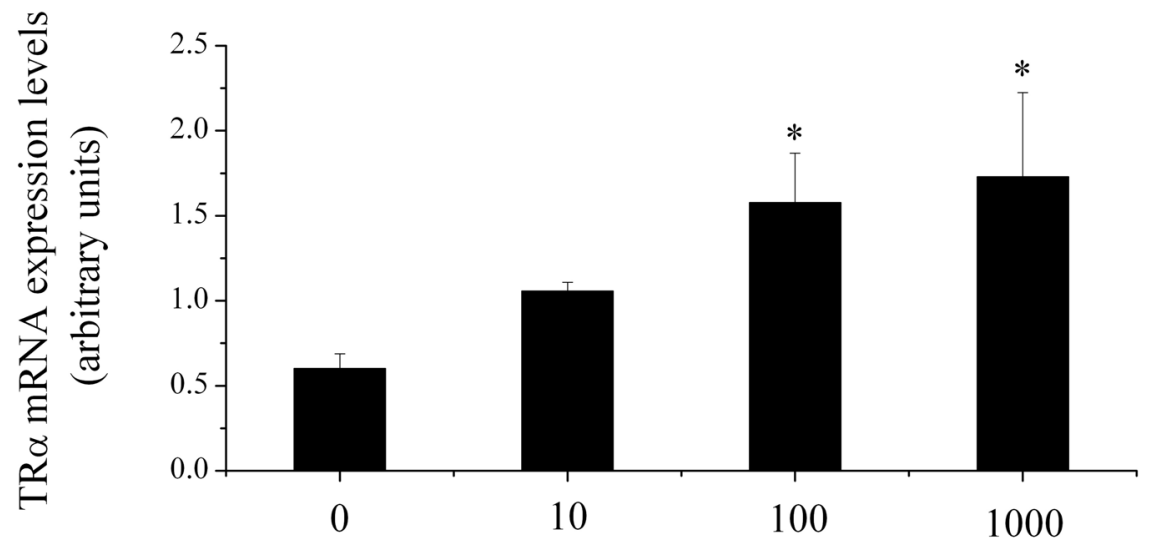

\section{Isoproterenol (nM)}

Figure 5. Relative TR $\alpha$ mRNA expression in subcutaneous adipose tissue explants from swine incubated in the presence of isoproterenol (0-1000 nM) for $24 \mathrm{~h}$ followed by extraction for total RNA and subsequent real-time RT-PCR analysis for TR $\alpha$ mRNA abundance. All values are reported as means $\pm \mathrm{SEM}$. *Isoproterenol effect $(\mathrm{P}<0.05, \mathrm{~N}=4)$.

\section{DISCUSSION}

In livestock, excessive fat deposition affects animal health and production efficiency. Reduction of fat deposition in adipose tissues of meat-producing animals is therefore highly desirable for both producers and consumers (Jiang et al., 2007).

In pigs, adipose tissue is the major site for fat synthesis. Regulation of fat mass is controlled by multiple neuroendocrine signals. Thyroid hormones are predominantly considered as hormones involved in adipose tissue development and metabolism (Levacher et al., 1984; Tuca et al., 1993). Their most obvious and well-known action is an increase in basal energy expenditure obtained acting on adipose tissue metabolism. Thyroid hormone exerts pleiotropic effects through modulation of gene expression by specific nuclear receptors (TR). TR $\alpha$ plays a central role in mediating the action of thyroid hormone and has been implicated as a major factor in the regulation of the development and function of adipose tissue (Liu et al., 2003; Jiang et al., 2004; Ortega et al., 2009; Mishra et al., 2010). Using the IMpRH panel, we first mapped the TR $\alpha$ gene to porcine chromosome 12 . According to the information from the Pig QTL Database (http://www.animalgenome.org/QTLdb/; Hu et al., 2007), some QTLs, including fat thickness at the shoulder, back fat at the 10th rib and belly weight, 
are on this chromosome. In addition, tissue distribution analysis also showed that the TR $\alpha$ gene was expressed at a higher level in white adipose tissue. Consequently, TR $\alpha$ may control fat deposition in pigs. We demonstrated that TR $\alpha$ expression levels in adipose tissue are decreased with age in Yorkshire pigs. Our results are similar to those reported by $\mathrm{Xu}$ (2002), who found that serum thyroid hormone levels decreased with age in Large White pigs. Aging in mammals is often associated with a relative increase in body adiposity (Mooradian and Albert, 1999). The increased adiposity may be a primary age-related phenomenon, or it could be secondary to environmental factors, including altered hormonal modulators of adipose metabolism. Thyroid hormone and its receptor are important modulators of lipid metabolism. We hypothesized that decreased TR $\alpha$ expression levels in porcine adipose tissue with age might be contributed to fat deposition in growing pigs. The Jinhua pig, a type of fatty pig from China, is characterized by its meat quality. In contrast, the Yorkshire pig is a lean breed noted for lean carcasses. Previous studies have shown obvious differences in the adipose tissue deposition rate between lean and fatty pig breeds (Miao et al., 2009). In our study, the mRNA levels of TR $\alpha$ in subcutaneous adipose tissue were associated with the fat percentage, Jinhua pigs had significantly lower TR $\alpha$ mRNA expression levels compared to Yorkshire pigs. Miao et al. (2008) also found a negative relationship between serum thyroid hormone levels and carcass fat content of pigs. These results indicate that thyroid hormone and its receptor $\mathrm{TR} \alpha$ may have a negative relationship with body adiposity in growing pigs, and subcutaneous fat expression of $\mathrm{TR} \alpha$ may directly influence functions of adipocytes. The mechanism underlying the regulation of adipose tissue metabolism by TR $\alpha$ in pigs is unclear. Jinhua pigs also had lower $\beta 2$-AR, HSL and ATGL mRNA expression levels compared to Yorkshire pigs. We hypothesize that $\mathrm{TR} \alpha$ regulates adipose tissue metabolism partly by promoting the expression of genes involved in lipolysis. We found no significant difference between PPAR $\gamma$ and SREBP-1C mRNA levels in Jinhua and Yorkshire pigs, suggesting that these transcription factors may not support a key role in the regulation of adipose tissue metabolism regulated by TR $\alpha$ in adipose tissue of pigs.

Lipolysis has been shown to be affected by physiological conditions and by hormones such as isoproterenol (Duncan et al., 2007). Isoproterenol is a non-selective $\beta$-AR agonist that can alter the expression of lipolysis-related genes in porcine adipocytes (Ramsay and Richards, 2007). Our study is the first to demonstrate that isoproterenol can induce TR $\alpha$ in subcutaneous adipose tissue of swine in vitro. We found that high doses of isoproterenol significantly increase the expression of $\mathrm{TR} \alpha$ in porcine adipose tissue explants. Various in vitro experiments have shown that isoproterenol and other $\beta$-adrenergic agonists stimulate lipolysis (Rule et al., 1987; Mersmann, 1998). Taken together, these results confirm that TR $\alpha$ plays a role in catecholamine-induced adipocyte lipolysis.

In conclusion, we localized porcine TR $\alpha$ to chromosome 12 by the radiation hybrid panel for the first time. The tissue expression results revealed that porcine TR $\alpha$ is expressed in all tissues. The mRNA levels of $\mathrm{TR} \alpha$ gene in subcutaneous adipose tissue decreased with age in growing pigs. In addition, we demonstrated clear differences in the expression of the TR $\alpha$ gene in fatty (Jinhua) versus lean (Yorkshire) breeds of pigs. In porcine adipose tissue explants, lipolysis and gene expression of TR $\alpha$ were found to be regulated by isoproterenol. These data provide molecular evidence for the roles played by $\mathrm{TR} \alpha$ in adipose tissue metabolism in pigs. This may also have practical applications for manipulation of lipid metabolism in pigs. 


\section{ACKNOWLEDGMENTS}

Research supported by grants from the National Natural Science Foundation of China (\#30972078) and the National S and T Major Project of China (\#2009ZX08006-009B).

\section{REFERENCES}

Duncan RE, Ahmadian M, Jaworski K, Sarkadi-Nagy E, et al. (2007). Regulation of lipolysis in adipocytes. Annu. Rev. Nutr. 27: 79-101.

Faulhaber JD, Klor HU and Ditschuneit H (1972). New device for preparing thin slices of adipose tissue for metabolic studies in vitro. J. Lipid Res. 13: 816-819.

Hu ZL, Fritz ER and Reecy JM (2007). Animal QTLdb: a livestock QTL database tool set for positional QTL information mining and beyond. Nucleic Acids Res. 35: D604-D609.

Jiang JP, Zhou J, Chen J and Wei XH (2007). Effect of chicken egg yolk antibody against adipose tissue plasma membranes on carcass composition and lipogenic hormones and enzymes in pigs. Livest. Sci. 107: 235-243.

Jiang W, Miyamoto T, Kakizawa T, Sakuma T, et al. (2004). Expression of thyroid hormone receptor alpha in 3T3L1 adipocytes; triiodothyronine increases the expression of lipogenic enzyme and triglyceride accumulation. $J$. Endocrinol. 182: 295-302.

Levacher C, Sztalryd C, Kinebanyan MF and Picon L (1984). Effects of thyroid hormones on adipose tissue development in Sherman and Zucker rats. Am. J. Physiol. 246: C50-C56.

Liu YY, Schultz JJ and Brent GA (2003). A thyroid hormone receptor alpha gene mutation (P398H) is associated with visceral adiposity and impaired catecholamine-stimulated lipolysis in mice. J. Biol. Chem. 278: 38913-38920.

Livak KJ and Schmittgen TD (2001). Analysis of relative gene expression data using real-time quantitative PCR and the $2^{-\Delta \Delta \mathrm{Ct}}$ Method. Methods 25: 402-408.

Mersmann HJ (1998). Overview of the effects of beta-adrenergic receptor agonists on animal growth including mechanisms of action. J. Anim. Sci. 76: 160-172.

Miao ZG, Wang LJ, Xu ZR and Huang JF (2008). Age-related changes of serum leptin, insulin, IGF-I and thyroid hormones levels in growing Jinhua and Landrace gilts. J. Anim. Feed Sci. 17: 548-558.

Miao ZG, Wang LJ, Xu ZR and Huang JF (2009). Developmental changes of carcass composition, meat quality and organs in the Jinhua pig and Landrace. Animal 3: 468-473.

Milan D, Hawken R, Cabau C, Leroux S, et al. (2000). IMpRH server: an RH mapping server available on the Web. Bioinformatics 16: 558-559.

Mishra A, Zhu XG, Ge K and Cheng SY (2010). Adipogenesis is differentially impaired by thyroid hormone receptor mutant isoforms. J. Mol. Endocrinol. 44: 247-255.

Mooradian AD and Albert SG (1999). The age-related changes in lipogenic enzymes: the role of dietary factors and thyroid hormone responsiveness. Mech. Ageing Dev. 108: 139-149.

Munoz A and Bernal J (1997). Biological activities of thyroid hormone receptors. Eur. J. Endocrinol. 137: 433-445.

Oppenheimer JH, Schwartz HL, Lane JT and Thompson MP (1991). Functional relationship of thyroid hormone-induced lipogenesis, lipolysis, and thermogenesis in the rat. J. Clin. Invest. 87: 125-132.

Ortega FJ, Moreno-Navarrete JM, Ribas V, Esteve E, et al. (2009). Subcutaneous fat shows higher thyroid hormone receptor-alpha1 gene expression than omental fat. Obesity 17: 2134-2141.

Pelletier P, Gauthier K, Sideleva O, Samarut J, et al. (2008). Mice lacking the thyroid hormone receptor-alpha gene spend more energy in thermogenesis, burn more fat, and are less sensitive to high-fat diet-induced obesity. Endocrinology 149: 6471-6486.

Picon L and Levacher C (1979). Thyroid hormones and adipose tissue development. J. Physiol. 75: 539-543.

Ramsay TG and Richards MP (2007). Beta-adrenergic regulation of uncoupling protein expression in swine. Comp. Biochem. Physiol. A. Mol. Integr. Physiol. 147: 395-403.

Rule DC, Smith SB and Mersmann HJ (1987). Effects of adrenergic agonists and insulin on porcine adipose tissue lipid metabolism in vitro. J. Anim. Sci. 65: 136-149.

Tuca A, Giralt M, Villarroya F, Vinas O, et al. (1993). Ontogeny of thyroid hormone receptors and c-erbA expression during brown adipose tissue development: evidence of fetal acquisition of the mature thyroid status. Endocrinology 132: 1913-1920.

Viguerie N, Millet L, Avizou S, Vidal H, et al. (2002). Regulation of human adipocyte gene expression by thyroid hormone. J. Clin. Endocrinol. Metab. 87: 630-634. 
Xu QF (2002). Regulation and Expression of Target Genes for Growth Hormone Action in Liver and Muscle of Pigs. DD Dissertation. Nanjing Agricultural University, Nanjing, 47-51.

Yen PM (2001). Physiological and molecular basis of thyroid hormone action. Physiol. Rev. 81: 1097-1142.

Yerle M, Pinton P, Robic A, Alfonso A, et al. (1998). Construction of a whole-genome radiation hybrid panel for highresolution gene mapping in pigs. Cytogenet. Cell Genet. 82: 182-188.

Ying H, Araki O, Furuya F, Kato Y, et al. (2007). Impaired adipogenesis caused by a mutated thyroid hormone alpha1 receptor. Mol. Cell Biol. 27: 2359-2371. 